\title{
Metabolic rate of neonates with congenital heart disease
}

\author{
ALFRED N. KRAUSS and PETER A. M. AULD \\ From the Department of Pediatrics, Cornell University Medical College, New York, New York
}

\begin{abstract}
Krauss, A. N., and Auld, P. A. M. (1975). Archives of Disease in Childhood, 50, 539. Metabolic rate of neonates with congenital heart disease. Seven infants under one month of age with controlled congestive heart failure showed a mean oxygen consumption of $9.4 \pm 1.6 \mathrm{SD} \mathrm{ml} / \mathrm{kg}$ per min, a mean respiratory quotient of $0.71 \pm 0.05 \mathrm{SD}$, and a mean metabolic rate of $63 \pm 12 \mathrm{SD} \mathrm{cal} / \mathrm{kg}$ per $24 \mathrm{~h}$. This compares with a group of infants with congenital heart disease not in heart failure with $\dot{\mathrm{V}}_{\mathrm{o} 2}$ of $6.5 \pm 1.2 \mathrm{SD} \mathrm{ml} / \mathrm{min}$ per $\mathrm{kg}$, respiratory quotient of $0 \cdot 80 \pm 0 \cdot 11 \mathrm{SD}$, and basal metabolic rate of $45 \pm 8 \mathrm{SD} \mathrm{cal} / \mathrm{kg}$ per $24 \mathrm{~h}$. These differences are significant $(P<0.001)$. The findings of a greater metabolic rate associated with congestive heart failure are thus extended to the newborn period.
\end{abstract}

Recent studies have shown that undergrown newborn infants have a raised metabolic rate when compared to those normally grown (Jonxis et al., 1968; Sinclair and Silverman, 1966). Infants with congenital heart disease have also been found to have raised metabolic rates in proportion to their degree of growth retardation and heart failure (Lees et al., 1965; Pittman and Cohen, 1964; Stocker et al., 1972). Only a few of these observations have been made on infants under one month of age. The present study was undertaken to provide information about the metabolic requirements of neonates with congenital heart disease during this critical period.

\section{Methods}

Fifteen infants ranging in birthweight from 1.25 to $4.8 \mathrm{~kg}$ were studied at ages ranging from $9 \mathrm{~h}$ to $60 \mathrm{~d}$. 5 infants were studied twice, the remainder once each. The diagnosis of congenital heart disease was made on the basis of heart murmurs, abnormal electrocardiogram or chest $x$-ray, or cyanosis without pulmonary disease. Profuse sweating was not observed. 12 patients underwent cardiac catheterization. 7 of these were diagnosed as having congestive heart failure on the basis of oedema, tachypnoea, and hepatosplenomegaly. These infants all received digitalis and diuretics before study, with reduction in clinical evidence of failure. 3 infants were studied after a balloon atrial septostomy (Rashkind procedure). Clinical details are presented in the Table.

Metabolic rate was determined by diaferometry using a Kipp-Noyons MG-4 diaferometer calibrated with

Received 1 December 1974.
$\mathrm{O}_{2}$ and $\mathrm{CO}_{2}$ at known flow rates. Infants were studied within one hour of feeding in an environment of $34-46^{\circ} \mathrm{C}$. All were breathing room air when studied. Measurements of $\mathrm{O}_{2}$ consumption $\left(\dot{\mathrm{V}}_{\mathrm{o} 2}\right)$ and $\mathrm{CO}_{2}$ production $\left(\dot{\mathrm{V}}_{\mathrm{co} 2}\right)$ were recorded for at least $20 \mathrm{~min}$. Results presented in the Table are the average of 4 or more readings during this time period. Respiratory quotient (RQ) was calculated as the ratio of mean $\dot{\mathrm{V}}_{\mathrm{co} 2} /$ mean $\dot{\mathrm{V}}_{\mathrm{o} 2}$. $\mathrm{Cal} / 24 \mathrm{~h}$ per $\mathrm{kg}$ were calculated using standard values for the caloric equivalent of $\mathrm{O}_{2}$ at a particular RQ (Lusk, 1924).

\section{Results}

The mean $\mathrm{V}_{\mathrm{O}_{2}}$ of neonates with congestive heart failure and congenital heart disease is $\mathbf{9 . 2}$ $\pm 1.5 \mathrm{SD} \mathrm{ml} / \mathrm{min}$ per $\mathrm{kg}$. This represents a basal caloric expenditure of $62 \pm 11 \mathrm{SD} \mathrm{cal} / \mathrm{kg}$ per $24 \mathrm{~h}$. For neonates with congenital heart disease not in congestive heart failure the comparable values are $\dot{\mathrm{V}}_{\mathrm{o} 2}$ of $6.5 \pm 1.2 \mathrm{ml} / \mathrm{min}$ per $\mathrm{kg}$ and metabolic rate of $45 \pm 7 \mathrm{cal} / \mathrm{kg}$ per $24 \mathrm{~h}$. These differences are significant $\left(\dot{\mathrm{V}}_{\mathrm{o} 2}, \mathrm{P}<0.001 ; \mathrm{cal}, \mathrm{P}<0.001\right)$. The mean RQ of infants in failure was $\mathbf{0 . 7 1} \pm \mathbf{0 . 0 5}$ $S D$, while those without failure had a mean RQ of $0.80 \pm 0.10(P=0.05)$. All 7 infants in congestive heart failure were studied at 11 days of age or later, while only 2 neonates not in failure were studied beyond the age of 10 days.

Normal infants over $1500 \mathrm{~g}$ at birth studied in this laboratory under similar conditions have a mean $\dot{\mathrm{V}}_{\mathrm{o} 2}$ of $6 \cdot 3 \pm 2 \cdot 1 \mathrm{SD} \mathrm{ml} / \mathrm{min}$ per $\mathrm{kg}$ at $1-4$ days of age, $7 \cdot 6 \pm 1 \cdot 7 \mathrm{ml} / \mathrm{min}$ per $\mathrm{kg}$ at one week, 
Clinical and metabolic data on neonaties

\begin{tabular}{|c|c|c|c|c|c|c|}
\hline Case no. & Birthweight (kg) & $\begin{array}{c}\text { Gestational } \\
\text { age }(w)\end{array}$ & $\begin{array}{l}\text { Study } \\
\text { age (d) }\end{array}$ & $\begin{array}{c}\text { Study } \\
\text { weight (kg) }\end{array}$ & $\begin{array}{c}\text { Surface } \\
\text { area }\left(\mathbf{m}^{2}\right)\end{array}$ & $\begin{array}{c}\dot{\mathrm{V}} \mathrm{CO}_{2} \\
(\mathrm{ml} / \mathrm{min})\end{array}$ \\
\hline \multicolumn{7}{|c|}{ Congestive heart failure } \\
\hline $\begin{array}{r}1 \\
2 \\
3 \\
4 \\
5 \\
6 \\
7 \\
8 \\
9 \\
10\end{array}$ & $\begin{array}{l}1 \cdot 94 \\
2 \cdot 47 \\
3 \cdot 26 \\
3 \cdot 50 \\
2 \cdot 38 \\
2 \cdot 55 \\
2 \cdot 90\end{array}$ & $\begin{array}{l}39 \\
40 \\
40 \\
40 \\
40 \\
40 \\
40\end{array}$ & $\begin{array}{l}25 \\
30 \\
24 \\
11 \\
14 \\
18 \\
22 \\
13 \\
16 \\
15\end{array}$ & $\begin{array}{l}1 \cdot 85 \\
1 \cdot 95 \\
2 \cdot 81 \\
2 \cdot 95 \\
2 \cdot 83 \\
2 \cdot 40 \\
2 \cdot 49 \\
2 \cdot 49 \\
2 \cdot 42 \\
3 \cdot 00\end{array}$ & $\begin{array}{l}0 \cdot 140 \\
0 \cdot 143 \\
0 \cdot 190 \\
0 \cdot 194 \\
0 \cdot 189 \\
0 \cdot 172 \\
0 \cdot 175 \\
0 \cdot 173 \\
0 \cdot 173 \\
0 \cdot 206\end{array}$ & $\begin{array}{l}12 \cdot 3 \\
18 \cdot 1 \\
20 \cdot 3 \\
15 \cdot 5 \\
24 \cdot 4 \\
14 \cdot 0 \\
13 \cdot 9 \\
12 \cdot 8 \\
18 \cdot 2 \\
15 \cdot 2\end{array}$ \\
\hline \multicolumn{7}{|c|}{ No congestive heart failure } \\
\hline $\begin{array}{l}11 \\
12 \\
13 \\
14 \\
15 \\
15 \\
17 \\
18 \\
19 \\
20\end{array}$ & $\begin{array}{l}4 \cdot 48 \\
1 \cdot 25 \\
2 \cdot 50 \\
4 \cdot 25 \\
3 \cdot 08 \\
1 \cdot 39 \\
2 \cdot 88 \\
3 \cdot 22\end{array}$ & $\begin{array}{l}40 \\
31 \\
40 \\
40 \\
39 \\
30 \\
40 \\
40\end{array}$ & $\begin{array}{c}3 \\
7 \\
60 \\
1 / 3 \\
10 \\
2 \\
24 \\
2 \\
5 \\
2\end{array}$ & $\begin{array}{l}4 \cdot 08 \\
4 \cdot 18 \\
1 \cdot 90 \\
2 \cdot 50 \\
3 \cdot 94 \\
3 \cdot 18 \\
1 \cdot 42 \\
2 \cdot 75 \\
2 \cdot 84 \\
3 \cdot 23\end{array}$ & $\begin{array}{l}0 \cdot 210 \\
0 \cdot 210 \\
0 \cdot 147 \\
0 \cdot 171 \\
0 \cdot 229 \\
0 \cdot 204 \\
0 \cdot 122 \\
0 \cdot 170 \\
0 \cdot 172 \\
0 \cdot 207\end{array}$ & $\begin{array}{r}16 \cdot 4 \\
19 \cdot 2 \\
10 \cdot 8 \\
14 \cdot 4 \\
18 \cdot 5 \\
14 \cdot 1 \\
8 \cdot 8 \\
14 \cdot 3 \\
15 \cdot 4 \\
16 \cdot 3\end{array}$ \\
\hline
\end{tabular}

$\star$ Mean \pm SD; PS, pulmonary stenosis; PDA, persistent ductus arteriosis; VSD, ventricular septal defect.

and $8.6 \pm 0.6 \mathrm{ml} / \mathrm{min}$ per $\mathrm{kg}$ at 2 weeks. Corresponding metabolic rates in cal/kg per $24 \mathrm{~h}$ are $44 \pm 13$ SD, $53 \pm 10,60 \pm 8$ (Krauss and Auld, 1969).

\section{Discussion}

The results obtained in this study for $\mathrm{O}_{2}$ consumption and metabolic rate of infants with congenital heart disease not in congestive heart failure are similar to those obtained in this laboratory for healthy neonates of the same age (Krauss and Auld, 1969). The findings of an increased rate in neonates with congestive heart failure confirms the findings of other investigators in older infants, children, and adults, and thus allows these observations to be extended to the newborn period (Brasel, 1968; Lees et al., 1965; Stocker et al., 1972). Though all infants with congestive heart failure showed poor weight gain, demonstrated by their failure to exceed birthweight as late as $\mathbf{3 0}$ days of age, the present study cannot answer the question as to the source of growth failure in congenital heart disease. As in all previous studies, the groups reported here are heterogeneous with respect to cyanosis, respiratory distress accompanying heart failure, and the severity of the congenital heart disease. Both increased myocardial work and the increased work of breathing may contribute to raised metabolic rate in congenital heart disease (Pittman and Cohen, 1964). Cyanosis shows no constant relation to metabolic rate (Stocker et al., 1972), though severe cyanosis in association with metabolic acidosis has been correlated with a decreased $\dot{\mathrm{V}}_{\mathrm{o} 2}$ (Levison, Delivoria-Papadopoulos and Swyer, 1965). Excessive sweating, which may contribute to heat loss, has also been reported in some infants with congenital heart disease (Taussig, 1960). Serial studies of relatively homogeneous groups of patients are needed to determine the causes of growth failure in congenital heart disease.

P. A. was supported by U. S. Public Health Research Grant HD-02644. A. K. held a Fellowship with the Tuberculosis and Respiratory Disease Association, and N.I.H. Research Career Development Award.

\section{REFBRENCES}

Brasel, J. A. (1968). Oxygen consumption and growth. Human Growth, p. 474. Ed. by D. B. Cheek. Lea and Febiger, Philadelphia. 
BLE

with congenital heart disease

\begin{tabular}{|c|c|c|c|c|}
\hline$\underset{(\mathrm{ml} / \mathrm{min})}{\dot{\mathrm{Vo}}}$ & $\begin{array}{c}\text { Respiratory } \\
\text { quotient } \\
\left(\dot{\mathrm{V}} \mathrm{CO}_{2} / \dot{\mathrm{VO}}_{2}\right.\end{array}$ & $\begin{array}{c}\dot{\text { Vog }} \\
(\mathrm{ml} / \mathbf{k g} \text { per min })\end{array}$ & Cal/kg per $24 \mathrm{~h}$ & Diagnosis \\
\hline $\begin{array}{l}18 \cdot 1 \\
23 \cdot 0 \\
27 \cdot 4 \\
24 \cdot 1 \\
31 \cdot 4 \\
20 \cdot 2 \\
20 \cdot 3 \\
17 \cdot 5 \\
24 \cdot 9 \\
23 \cdot 5\end{array}$ & $\begin{array}{l}0 \cdot 68 \\
0 \cdot 79 \\
0 \cdot 74 \\
0 \cdot 64 \\
0 \cdot 78 \\
0 \cdot 69 \\
0 \cdot 68 \\
0 \cdot 73 \\
0 \cdot 73 \\
0 \cdot 63\end{array}$ & $\begin{array}{r}9 \cdot 8 \\
11 \cdot 7 \\
9 \cdot 8 \\
8 \cdot 2 \\
11 \cdot 1 \\
8 \cdot 4 \\
8 \cdot 1 \\
7 \cdot 0 \\
10 \cdot 3 \\
7 \cdot 8\end{array}$ & $\begin{array}{l}64 \\
81 \\
67 \\
53 \\
76 \\
54 \\
52 \\
48 \\
70 \\
52\end{array}$ & $\begin{array}{l}\text { VSD } \\
\text { PS, PDA, congenital rubella } \\
\text { Transposition, VSD, coarctation } \\
\text { Tricuspid atresia } \\
\text { Single ventricle } \\
\text { Atrioventricular canal, PDA } \\
\text { Coarctation aorta }\end{array}$ \\
\hline \multirow{3}{*}{$\begin{array}{l}27 \cdot 3 \\
23 \cdot 5 \\
13 \cdot 5 \\
18 \cdot 8 \\
20 \cdot 7 \\
15 \cdot 9 \\
12 \cdot 6 \\
15 \cdot 1 \\
18 \cdot 5 \\
20 \cdot 4\end{array}$} & $0.71 \pm .05^{\star}$ & $9 \cdot 2 \pm 1 \cdot 5^{\star}$ & $62 \pm 11^{\star}$ & \\
\hline & $\begin{array}{l}0 \cdot 60 \\
0 \cdot 82 \\
0 \cdot 80 \\
0 \cdot 76 \\
0 \cdot 90 \\
0 \cdot 89 \\
0 \cdot 70 \\
0 \cdot 94 \\
0 \cdot 83 \\
0 \cdot 80\end{array}$ & $\begin{array}{l}6 \cdot 7 \\
5 \cdot 6 \\
7 \cdot 1 \\
7 \cdot 5 \\
5 \cdot 3 \\
5 \cdot 2 \\
8 \cdot 9 \\
5 \cdot 5 \\
6 \cdot 5 \\
6 \cdot 3\end{array}$ & $\begin{array}{l}44 \\
39 \\
49 \\
51 \\
38 \\
37 \\
60 \\
39 \\
45 \\
44\end{array}$ & $\begin{array}{l}\text { Transposition of great vessels } \\
\text { Fallot's tetralogy } \\
\text { VSD } \\
\text { Tranposition of great vessels } \\
\text { VSD, Down's syndrome } \\
\text { PDA } \\
\text { Single ventricle, pulmonary atresia } \\
\text { Transposition of great vessels }\end{array}$ \\
\hline & $\begin{array}{l}0.80 \pm \cdot 10^{\star} \\
t=2 \cdot 646 \\
P=0.05\end{array}$ & $\begin{array}{l}\quad 6 \cdot 5 \pm 1 \cdot 2^{\star} \\
t=4 \cdot 200 \\
P<0.001\end{array}$ & $\begin{array}{r}45 \pm 7 \\
t=3.991 \\
P<0.001\end{array}$ & \\
\hline
\end{tabular}

Jonxis, J. H. P., Van der Vlugt, J. J., de Groot, C. J., Boersma, E. R., and Meijers, E. D. K. (1968). The metabolic rate in premature, dysmature and sick infants in relation to environmental temperature. Aspects of Prematurity and Dysmaturity, p. 201. Ed. by J. H. P. Jonxis, H. K. A. Visser, and J. A. Troelstra. Stenfert Kroese, Leiden.

Krauss, A. N., and Auld, P. A. M. (1969). Metabolic requirements of low-birth-weight infants. Fournal of Pediatrics, 75, 952.

Lees, M. H., Bristow, J. D., Griswold, H. E., and Olmsted, R. W. (1965). Relative hypermetabolism in infants with congenital heart disease and undernutrition. Pediatrics, 36, 183.

Levison, H., Delivoria-Papadopoulos, M., and Swyer, P. R. (1965). Variations in oxygen consumption in the infant with hypoxaemia due to cardiopulmonary disease. Acta Paediatrica Scandinavica, 54, 369.

Lusk, G. (1924). Animal calorimetry: analysis of the oxidation mixtures of carbohydrate and fat. Fournal of Biological Chemistry, 59, 41.
Pittman, J. G., and Cohen, P. (1964). The pathogenesis of cardiac cachexia. New England fournal of Medicine, 271, 403.

Sinclair, J. C., and Silverman, W. A. (1966). Intrauterine growth in active tissue mass of the human fetus, with particular reference to the undergrown baby. Pediatrics, 38, 48.

Stocker, F. P., Wilkoff, W., Miettinen, O. S., and Nadas, A. S. (1972). Oxygen consumption in infants with heart disease. fournal of Pediatrics, 80, 43.

Taussig, H. B. (1960). Congenital Malformations of the Heart, revised ed., vol. II. pp. 697, 915, 926. Harvard University Press, Cambridge, Massachusetts.

Correspondence to Dr. A. N. Krauss, The New York Hospital, Cornell Medical Center, 525 East 68th Street, New York, N.Y. 10021, U.S.A. 